\title{
КЛІНІКО-ПАТОГЕНЕТИЧНЕ ОБҐРУНТУВАННЯ ДІЄВОСТІ БІОРЕГУЛЯЦІЙНОГО ПРЕПАРАТУ ТРАУМЕЛЬ С У ЛІКУВАННІ ТА ПРОФІЛАКТИЦІ УСКЛАДНЕНЬ ГОСТРИХ РЕСПІРАТОРНИХ ІНФЕКЦІЙ
}

\author{
๑л. С. Бабінець, М. А. Гулій, Н. Г. Лерман \\ Тернопільський національний медичний університет імені І. Я. Горбачевського МОЗ України \\ НЗ «Українська Академія біорегуляційної медицини»
}

РЕЗЮМЕ. Щороку в Україні реєструється 4,0-4,8 млн випадків гострих респіраторних інфекцій (ГРІ) та грипу, що робить тему дослідження актуальною. Найраціональнішим підходом до ведення пацієнтів з ГРІ $\epsilon$ профілактичний. Саме тому останніми роками все частіше до загальновизнаної у світі тактики ведення хворих з ГРІ «Очікуй і спостерігай» науковці і практики рекомендують ад'ювантні засоби, котрі підвищують опірність організму до інфекцій і відновлюють порушені функції органів і систем хворої людини.

Мета - вивчення ефективності застосування препарату Траумель С при неускладненій гострій респіраторній інфекції у дорослих і дітей для профілактики виникнення ускладнень верхніх і нижніх дихальних шляхів запального ґенезу.

Матеріал і методи. Для досягнення поставленої мети було проведено багатоцентрове відкрите проспективне порівняльне клінічне випробовування на 300 пацієнтах (200 дорослих і 100 дітей) з підтвердженим діагнозом ГРІ. Тривалість дослідження склала 21 день: курс лікування - 14 днів, період спостереження - 7 днів. У випробовуванні брали участь дорослі (чоловіки та жінки віком 18-65 років) і діти обох статей (віком 1-18 років).

Результати. Встановлено статистично достовірно вищу дієвість комплексного лікування із включенням до нього курсу таблетованого Траумелю С щодо купірування клінічної симптоматики ГРІ у пацієнтів - дорослих і дітей $(p \leq 0,05)$, а також щодо запобіганню ускладнень запального характеру (ускладнення мали лише 10,0 \% пацієнтів групи з Траумелем С і 47,0 \% - пацієнтів групи стандартного лікування), що сприяло достовірно нижчій потребі у застосуванні НПЗП і антибіотиків (лише 15,0 \% пацієнтів групи з Траумелем С потребували НП3П і 2,0 \% - антибіотиків, проти 64,0 \% і 33,0 \% відповідно пацієнтів групи стандартної терапії).

Висновки. Ефективність лікування із включенням Траумелю С була вищою, порівняно зі стандартним лікуванням: за зменшенням на 12,5 \% показника лейкоцитів, на 11,8 \% - паличкоядерних лейкоцитів, на 11,4 \% - сегментів, на 6,6 \% - ШОЕ, на 81,5 \% - С-реактивного протеїну, на 9,6 \% - за збільшенням лімфоцитів $(p \leq 0,05)$.

3. Доведено вищу дієвість лікувального комплексу, посиленого курсом Траумелю С, на всі патологічно змінені параметри загального аналізу крові пацієнтів дитячого віку: зменшення на 9,5 \% показника лейкоцитів, на $11,8 \%$ - паличкоядерних лейкоцитів, на 6,7 \% - сегментів, на 8,8 \% - еозинофілів, на 23,9 \% - ШОЕ, на 67,7 \% С-реактивного протеїну $(p \leq 0,05)$.

КЛючОВІ СЛОВА: гостра респіраторна інфекція; грип; біорегуляційний препарат; розрішення запалення; лікування і профілактика ускладнень; Траумель С.

Вступ. Гострі респіраторні інфекції (ГРІ) - це зазвичай легкі інфекції слизових оболонок дихальних шляхів, у більшості випадків викликані вірусами [1]. Вони $є$ найчастішою причиною звернення до сімейного лікаря, однією з трьох найчастіших причин госпіталізації, третьою причиною тимчасової непрацездатності, що визначає позицію ГРІ як значної проблеми охорони здоров'я [2]. Крім вірусів, причиною ГРІ можуть бути бактерії й, рідше, гриби та інші умовно-патогенні інфекції. Бактеріальна суперінфекція при ГРІ $\epsilon$ відносно частим ускладненням, що подовжує і ускладнює їх перебіг [1]. Профілактика ГРІ та їх ускладнень є надзвичайно актуальною проблемою загальнолікарської практики, оскільки ГРІ - це нозології з високою частотою захворювання у людей будь-якої вікової категорії. Однак частота ГРІ зменшується з віком: діти хворіють на ГРІ п'ять - сім, дорослі - в середньому два рази на рік, тоді як батьки з маленькими дітьми хворіють трохи частіше, ніж інші дорослі [3].
Щороку в Україні реєструється 4,0-4,8 млн випадків ГРІ та грипу. За даними МОЗ України, у 2019 р. на грип та ГРІ перехворіло 5,4 млн людей, 65,3 \% яких - діти віком до 17 років [4]. Рівень захворюваності на ГРІ перевищує рівень всіх інших інфекцій, при цьому серед дітей в 7,0-7,7, а серед дорослих - у 1,5-3 рази $[5,6]$. За даними Всесвітньої організації охорони здоров'я (ВООЗ), ця найпоширеніша в людській популяції група захворювань останніми роками постійно зростає $[7,8]$. Особливо тяжко ГРІ перебігають у маленьких дітей та літніх людей - пацієнтів так званої «групи ризику» [6]. Імунна система дітей і підлітків України сьогодні формується під впливом несприятливої інфекційної ситуації, що зумовлено надзвичайно високим ризиком анте- і неонатального інфікування. Сильна інтоксикація може призвести до небажаних наслідків, особливо це стосується людей похилого віку з хронічними захворюваннями $[9,10]$. Рівень смертності, наприклад, від 
Огляди літератури, оригінальні дослідження, погляд на проблему, випадок з практики, короткі повідомлення ускладнень грипу становить 0,3 \% по всьому світу [11]. Збудник інфекції передається повітряно-крапельним шляхом - найлегшим із чотирьох відомих механізмів зараження, що дає змогу збудникові грипу в разі відсутності імунітету швидко розповсюджуватись у континентальному і навіть глобальному масштабах $[5,12]$. Однак на даний момент відсутнє специфічне лікування ГРІ, засноване на засадах доказовості [13], і МО3 рекомендує лише обмежений перелік медикаментів (противірусних із значною кількістю протипоказань і засобів симптоматичної терапії, зокрема, нестероїдних протизапальних препаратів (НПЗП) при лихоманці тощо. [4]. Це збільшує можливість виникнення побічних ефектів, а також ускладнень ГРІ з боку інших органів і систем [14-16].

Доказово встановлено, що ГРІ знижують резистентність імунітету і примушують «прокидатися» хронічні захворювання, особливо серед груп ризику - діти, вагітні і особи похилого віку. Вони вкрай небезпечні саме своїми ускладненнями (легеневими (пневмонія, бронхіт), верхніх дихальних шляхів і лОР-органів (отит, синусит), серцевосудинної системи (міокардит) тощо), що вимагатиме призначення антибактеріальної терапії - дієвої, однак такої, що сприяє іншим медико-соціальним проблемам-формуванню імунодефіцитів і дисбіозів у пацієнтів, виникненню розладів суміжних органів і систем, а також антибіотикорезистентності $[17,18]$.

3 огляду на вищенаведене можна констатувати, що найраціональнішим підходом до ведення пацієнтів з ГРІ є профілактичний. Він зменшує ризик виникнення можливих ускладнень шляхом оптимізації стану імунної системи і гармонійного завершення запального процесу внаслідок агресії вірусних та інших патогенів. Саме тому останніми роками все частіше до загальновизнаної у світі тактики ведення хворих з ГРІ «Очікуй і спостерігай» науковці і практики рекомендують ад' ювантні засоби, котрі підвищують опірність організму до вірусних та інших інфекцій і відновлюють порушені функції органів і систем хворої людини. Коло препаратів, які з цією метою можна використовувати безпечно для пацієнтів з ГРІ, особливо для дітей молодшого і людей похилого віку, обмежене, що зумовлено їх токсичністю, побічними діями та низькою ефективністю. Цих недоліків позбавлені біорегуляційні препарати (БРП), або комплексні гомеопатичні препарати. БРП, поряд з високою ефективністю, не виявляють токсичної та алергічної дії, а також не викликають ускладнень, тому їх можна приймати впродовж необмежено тривалого часу та в комплексі з будь-якими іншими методами лікування. До таких БРП належить препарат Траумель С («Біологіше Хайльміт-

тель Хеель ГмбХ», Баден-Баден, Німеччина; реєстраційне посвідчення №AU5934/03/01), який було створено на основі наукових здобутків видатного німецького вченого Ганса-Генріха Рекевега. На сьогодні існує успішний практичний досвід використання цього препарату понад 84 роки у більш ніж 50 країнах світу. Станом на сьогодні Траумель С та інші БРП мають офіційний статус і занесені до Європейської та низки національних фармакопей, в тому числі й до Німецької гомеопатичної фармакопеї (GHP), Французької гомеопатичної фармакопеї (PFX), Гомеопатичної фармакопеї США (HPUS), Британської гомеопатичної фармакопеї (ВНР), а також до Державної фармакопеї України. Наукові дослідження останніх років дозволяють позиціонувати Траумель С як універсальний препарат для ефективного лікування запалення при різних патологічних станах [19, 20], у тому числі й при ГРІ [21-24]. Препарат не просто блокує запалення, а сприяє повній реалізації його як захисного процесу, не даючи хворобам перейти у хронічну фазу, що, власне, й пояснює предикторну дію Траумелю С щодо ускладнень. Запобігання виникненню ускладнень може реалізуватися через оптимізацію і корекцію перебігу запального процесу шляхом допоміжної імунної реакції [25] і активізації утворення пророзрішуючих ліпідних медіаторів [19], що блокує хронізацію запалення і призводить до швидшого одужання. Крім того, доведено, що Траумель С не порушує нормальні гомеостатичні процеси і не має негативного впливу на функцію нирок і печінки, що й забезпечує практично повну відсутність побічних ефектів $[26,27]$.

Клінічних випробувань ефективності застосування препарату Траумель С у таблетованій формі для профілактики ускладнень при ГРІ і грипі не проводилось, тому ми вважали за доцільне провести таке науково-практичне дослідження.

Мета - вивчення ефективності застосування препарату Траумель С при неускладненій гострій респіраторній інфекції у дорослих і дітей для профілактики виникнення ускладнень верхніх і нижніх дихальних шляхів запального ґенезу.

Матеріал і методи дослідження. Для досягнення поставленої мети було проведено багатоцентрове відкрите проспективне порівняльне клінічне випробовування на 300 пацієнтах (200 дорослих і 100 дітей) з підтвердженим діагнозом гострої респіраторної інфекції згідно із Наказом № 499 від 16.07.2014 «Про затвердження та впровадження медико-технологічних документів зі стандартизації медичної допомоги при грипі та гострих респіраторних інфекціях» і Наказом МОЗ України № 1126 від 17.05.2019 «Про затвердження Порядку організації проведення епідеміоло- 
Огляди літератури, оригінальні дослідження, погляд на проблему, випадок з практики, короткі повідомлення гічного нагляду за грипом та гострими респіраторними вірусними інфекціями, заходів з готовності в міжепідемічний період...». Дослідження проводили на клінічних базах: в амбулаторії № 1 Центру ПМСД Печерського району м. Київ; денному стаціонарі НКП «Тернопільська міська комунальна лікарня № 2» і Центрі ПМСД м. Тернопільдорослі; у ФОП «Кабінет сімейного лікаря Стецюк Л. С." у м. Фастів Київської області - діти.

Випробовування проводили в декілька етапів:

1) визначено найпоширеніші ускладнення після ГРЗ, а також їх частоту в дорослих і дітей методом проведення статистичного дослідження серед пацієнтів сімейних лікарів і дільничних педіатрів України;

2) проведено порівняльний аналіз частоти виникнення і характеру ускладнень у пацієнтів 3 діагнозом ГРІ на тлі загальноприйнятої протокольної терапії і такої із додаванням курсу препарату Траумель С;

3) оцінено тяжкість перебігу ГРІ у пацієнтів, що отримували загальноприйняту протокольну терапію і таку із включенням курсу Траумель С.

Тривалість дослідження склала 21 день: курс лікування - 14 днів, період спостереження - 7 днів. У випробовуванні брали участь дорослі (чоловіки та жінки віком 18-65 років) і діти обох статей (віком 1-18 років). Критеріями включення пацієнтів були: діагностована інфекція верхніх дихальних шляхів із наявністю симптомів не більше 72 годин: температура тіла $\geq 37,1^{\circ} \mathrm{C}$; вираження загальних симптомів за вербально-аналоговою шкалою $\geq 2$ балів; письмова інформована згода на участь у дослідженні і на збір даних; відсутність критеріїв виключення. Критеріями виключення пацієнтів вважали тяжкість захворювання, яка потребує лікування в умовах стаціонару; тяжкий чи ускладнений перебіг інфекційного захворювання верхніх дихальних шляхів; будь-яке хронічне захворювання (захворювання ЛОР чи дихальної системи, яке потребує системної антибактеріальної терапії; обструктивні анатомічні зміни в носоглотці; вроджені вади серця, нирок чи печінки у дітей; серцеві захворювання (застійна серцева недостатність III або IV класу), ВІЛ-інфекція, неконтрольований цукровий діабет, целіакія, імуносупресивні стани або ті, які потребують імуносупресивної терапії; бронхіальна астма; муковісцидоз у дітей; ХОЗЛ (III або IV стадії)); аритмії; суб' єкти, які не можуть приймати пероральні препарати; психічно хворі; будь-який медичний чи соціальний стан, який, на думку лікаря, перешкоджає можливості безпечної участі пацієнта в дослідженні та його завершенні; суб' єкти, які, на думку дослідника, не будуть дотримуватись вимог протоколу; відмова від участі в дослідженні у будь-який час; розвиток будь-якого ускладнення,

що вимагає призначення додаткового лікування (антибактеріальна терапія, гормонотерапія) або госпіталізації; некомплаєнтні пацієнти.

План дослідження. Візит 1 - включення пацієнта в дослідження: підписання інформованої згоди, збір анамнестичних даних та об'єктивне обстеження (демографічні та антропометричні дані: вік, стать, зріст, маса тіла, індекс маси тіла, фізикальне обстеження та показники життєво важливих функцій: температура тіла, артеріальний тиск, пульс (частота серцевих скорочень) та частота дихальних рухів), оцінка відповідності пацієнта критеріям включення/не включення, оцінка стану пацієнта за вербально-аналоговою шкалою (табл. 1), призначення лабораторних аналізів і лікування; Візит 2 - через 1 тиждень: оцінка загального стану; оцінка ефективності терапії (може проводитись по телефону); Візит 3 - через 2 тижні: оцінка ефективності терапії - опитування пацієнта, об' єктивне обстеження, оцінка стану пацієнта за вербальною аналоговою шкалою, призначення повторних лабораторних аналізів і корекція лікування; Візит 4 (закінчення дослідження) - через 3 тижні - оцінка стану пацієнта за вербальноаналоговою шкалою проводилася під час візиту чи при телефонній розмові.

Пацієнти з ГРІ були поділені на дві групи за лікувальними програмами:

1) основна група отримувала стандартне лікування, яке включало амбулаторний режим, харчування із зменшенням кількості білка у раціоні, пиття додатково до раціону 1,5-2,0 л (чаї з лимоном, малиною, липою), аскорбінову кислоту по 500 мг двічі на день, симптоматичне лікування «за вимогою» (жарознижувальні (парацетамол, ібупрофен) при температурі тіла вище $38,5^{\circ} \mathrm{C}$; судинозвужувальні при сильному нежиті не більше 3-х днів, місцеві антисептики - при болю в горлі) із виключенням противірусних препаратів, антибактеріальної терапії; додатково пацієнти отримували БРП Траумель С за наступною схемою: в 1-й день захворювання - 1 таблетка (сублінгвально) кожні 15 хвилин протягом 2 годин, далі 1 таблетка 3 рази на день за 15-20 хвилин до або через годину після їди протягом двох тижнів; 2) контрольна група отримувала лише стандартне лікування.

Основними параметрами ефективності дослідження вважали відсутність захворювань верхніх і нижніх дихальних шляхів запального ґенезу, котрі розцінюються як ускладнення ГРІ. Додатковими параметрами ефективності вважали тяжкість перебігу ГРІ і її тривалість. Оцінка безпеки проводилась за суб' єктивними і об' єктивними клінічними симптомами пацієнта. Загальний аналіз крові і визначення С-реактивного протеїну проводилося за загальноприйнятими у клініці методиками. 
Огляди літератури, оригінальні дослідження, погляд на проблему, випадок з практики, короткі повідомлення

Таблиця 1. Вербально-аналогова шкала для визначення основних клінічних симптомів

\begin{tabular}{|c|c|c|c|c|c|}
\hline \multirow{3}{*}{ Клінічна ознака } & \multirow{3}{*}{ Характеристика клінічної ознаки } & \multicolumn{4}{|c|}{ Бал } \\
\hline & & \multicolumn{4}{|c|}{ (відсутність ознаки - 0, наявність - 1) } \\
\hline & & візит 1 & візит 2 & візит 3 & візит 4 \\
\hline Температура тіла & Підвищення температури тіла вище $37,1^{\circ} \mathrm{C}$ & & & & \\
\hline Закладеність носа & Утруднене носове дихання & & & & \\
\hline Біль у горлі & $\begin{array}{l}\text { Наявність болю, відчуття «першіння», } \\
\text { почервоніння, набряку }\end{array}$ & & & & \\
\hline Дихання & $\begin{array}{l}\text { Нерегулярне/ускладнене/ } \\
\text { поверхневе дихання; дихання через рот }\end{array}$ & & & & \\
\hline $\begin{array}{l}\text { Частота серцевих } \\
\text { скорочень }\end{array}$ & $\begin{array}{l}\text { 36ільшення і/або зниження частоти } \\
\text { серцевих скорочень }\end{array}$ & & & & \\
\hline Кашель & $\begin{array}{l}\text { Наявність кашлю будь-якого характеру (сухий, } \\
\text { вологий); хрипи та «булькотіння» в грудній клітці }\end{array}$ & & & & \\
\hline Головний біль & Наявність цього симптому протягом 1-2 днів & & & & \\
\hline $\begin{array}{l}\text { Відчуття болю/ } \\
\text { тиску в гайморових } \\
\text { пазухах }\end{array}$ & Наявність даного симптому протягом дня & & & & \\
\hline Біль у вухах & Наявність даного симптому протягом дня & & & & \\
\hline $\begin{array}{l}\text { Загальне } \\
\text { самопочуття }\end{array}$ & $\begin{array}{l}\text { Погіршення загального стану, відчуття ломоти в } \\
\text { тілі, біль у м'язах, озноб }\end{array}$ & & & & \\
\hline & Сумарний бал & & & & \\
\hline
\end{tabular}

Статистичний аналіз проводили за допомогою пакета комп' ютерних програм Microsoft Excel, адаптованих для медико-біологічних досліджень, з використанням методів варіаційної статистики, кореляційного, дисперсійного та дискретно-динамічного аналізу. Різницю параметрів вважали достовірною при значенні показника Стьюдента p $\leq 0,05$.

Результати й обговорення. На 1-у етапі дослідження було проаналізовано спектр клінічних форм і ускладнень ГРІ (у т. ч. грипу) серед пацієнтів (дітей і дорослих) за даними опитування і статистичної звітності 162 лікарів амбулаторної ланки з різних міст України. Серед них було сімейних лікарів - $37 \%$, терапевтів - $27 \%$, педіатрів - $35 \%$ та імунологів - 1 \%. Усього протягом 1.10.201831.03.2019 рр. було зафіксовано 109786 випадків ГРІ. Кількість ускладнених форм ГРІ становила 16064 випадків (до 15 \% від усіх проаналізованих випадків ГРІ).

Як свідчать результати проведеного аналізу (рис. 1), найчастіше ГРІ, крім інтоксикаційного і астено-вегетативного синдромів, проявлялося синдромом ураження верхніх і нижніх дихальних шляхів - бронхітом (2059 випадків), синуситом (1519 випадків) і гайморитом (1213 випадків), ларингітом (1463 випадки), ангіною (1229 випадків). Всі ураження і ускладнення ГРІ (загострення БА та ХОЗЛ, міокардит тощо) мають запальний характер, що мотивує до необхідності посилення терапевтичного впливу на синдром запалення з метою попередження тяжких форм ГРІ та хронізації перерахованих вище клінічних форм ГРІ.
Слід вказати, що у проведеному дослідженні розподіл клінічних форм і ускладнень ГРІ, що були констатовані лікарями різних спеціальностей (рис. 2) був наступним: бронхіт найчастіше діагностували сімейні лікарі, педіатри і терапевти (відповідно 15,3\%, 10,4 \% та 13,5 \%), гайморит найбільше вели імунологи - (у 18,9 \% випадків). Наведені дані є притаманними лише даній вибірці, оскільки не брали участі в дослідження такі категорії спеціалістів, як ЛОРи, пульмонологи, інфекціоністи, неврологи та ін. Однак проведений аналіз акцентує велику роль лікарів первинної ланки у веденні пацієнтів з ГРІ. Це дуже важливо, оскільки профілактичний характер лікування при веденні таких хворих на первинній ланці зменшив би навантаження на спеціалістів вторинної ланки (імунологів у тому числі), залишивши їм лише надскладні випадки. Ад'ювантне посилення протокольної терапії ГРІ засобами імунотропної та оптимізуючої запалення дії з огляду на це $\epsilon$ доцільним.

Щодо частоти виявлення різних клінічних форм і ускладнень ГРІ серед пацієнтів дитячого віку, які були включені в дослідження, то найчастіше діагностували бронхіт і ларингіт - у 10,4 \% і 10,2 \% відповідно, дещо рідше - отит і синусит - у 9,5 \% й 9,4 \% випадків відповідно.

За даними проведеного дослідження, для лікування ГРІ (рис. 4) у дорослих і дітей у 32 \% випадків застосовували противірусні засоби, хоча за рекомендаціями світових протоколів і МОЗ України таке лікування не має достатньої доказової 
Огляди літератури, оригінальні дослідження, погляд на проблему, випадок з практики, короткі повідомлення бази $[4,7,11,17]$. у 28 \% випадків ГРІ застосовували симптоматичне лікування, зокрема, жарознижувальні засоби, нПЗП, судинозвужувальні краплі. Ефективність останніх $є$ сумнівною, а довго-

тривале використання НПЗП і судинозвужувальних препаратів є шкідливим, особливо у дітей, людей похилого віку і пацієнтів $з$ хронічними захворюваннями $[14,15,16]$.

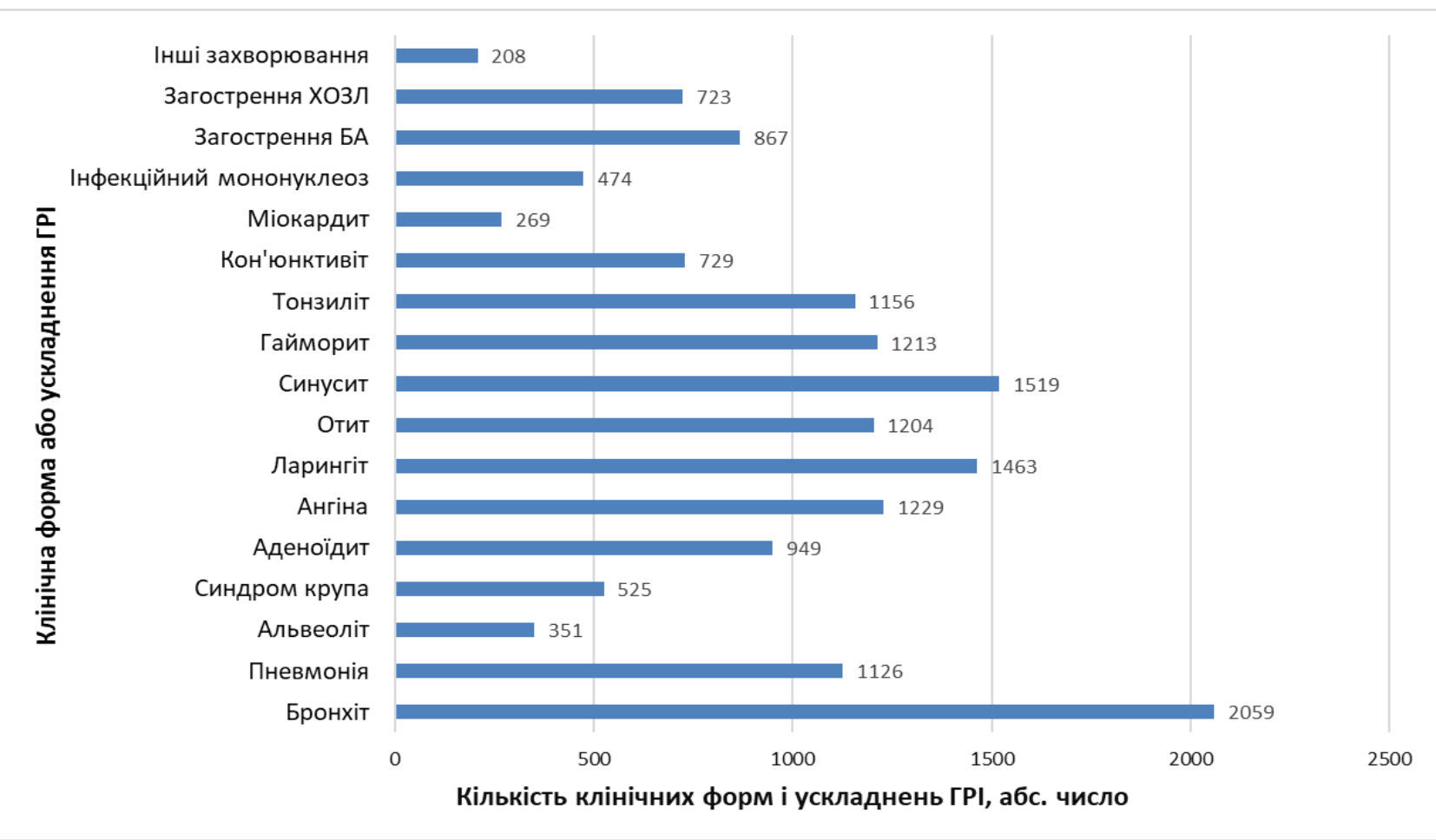

Рис. 1. Аналіз клінічних форм і ускладнень проаналізованих випадків ГРІ серед дорослих і дітей за період 1.10.2018-31.03.2019 рр.

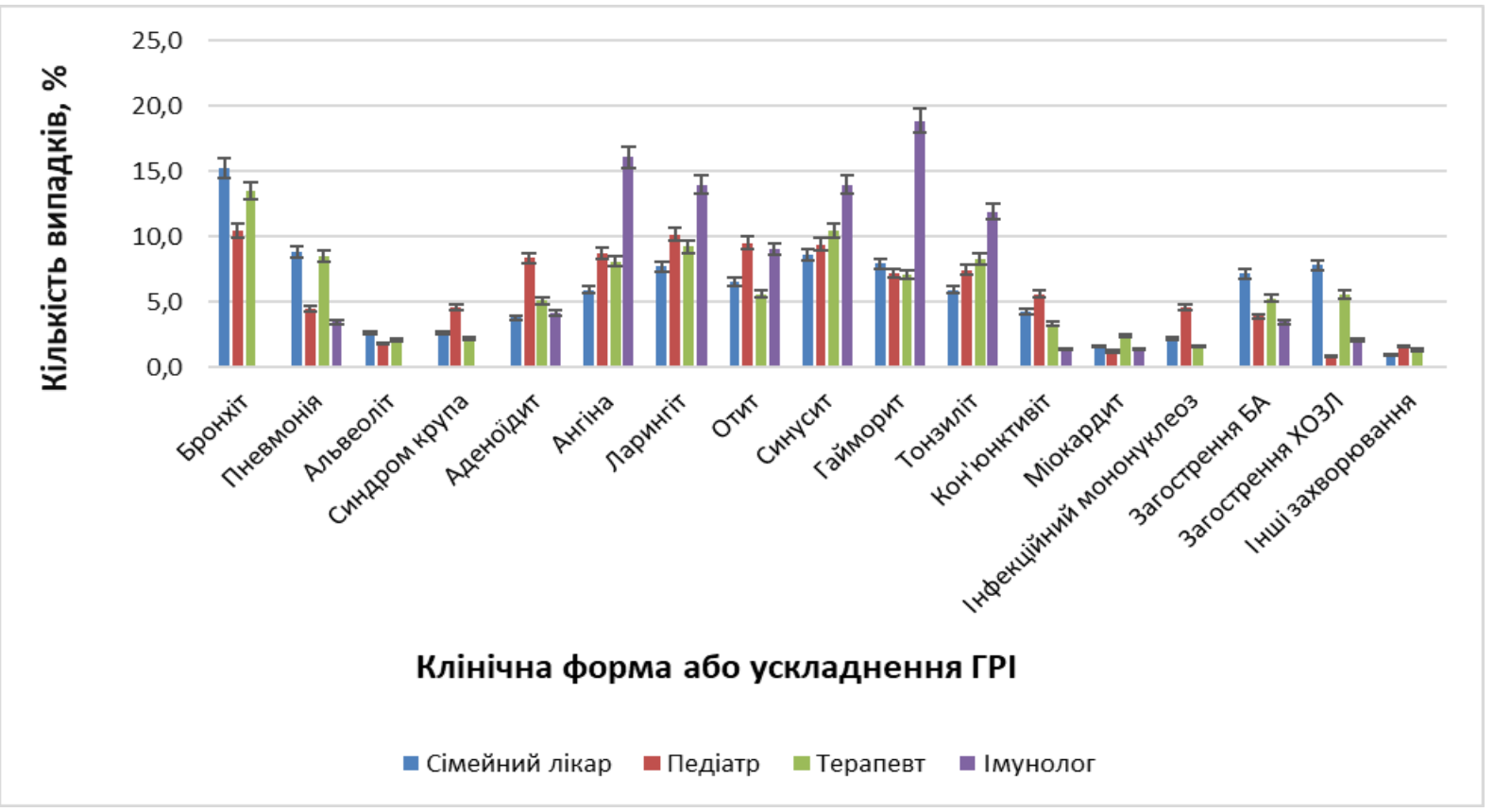

Рис. 2. Частота виявлення клінічних форм і ускладнень ГРІ лікарями різних спеціальностей у когорті пацієнтів даного дослідження $(p \leq 0,05)$. 
Огляди літератури, оригінальні дослідження, погляд на проблему, випадок з практики, короткі повідомлення

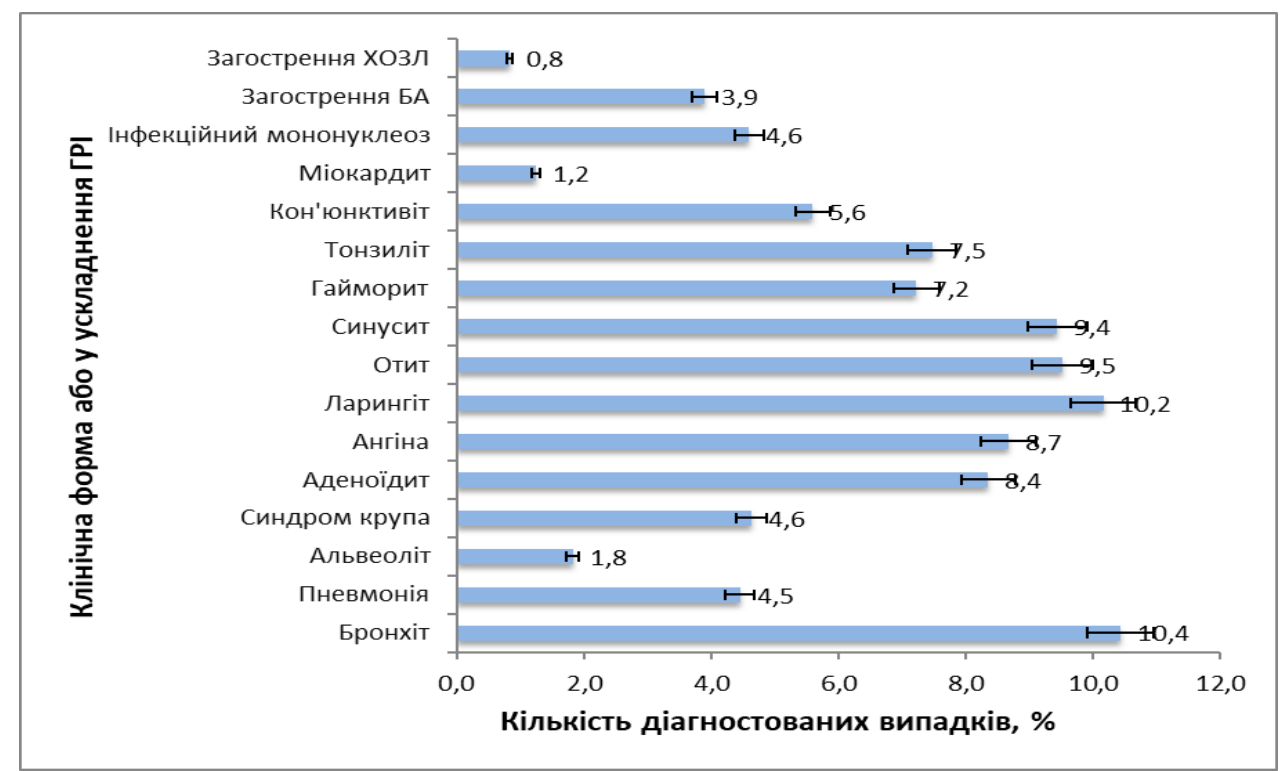

Рис. 3. Частота та види діагностованих клінічних форм і ускладнень ГРІ серед пацієнтів дитячого віку $(p \leq 0,05)$.

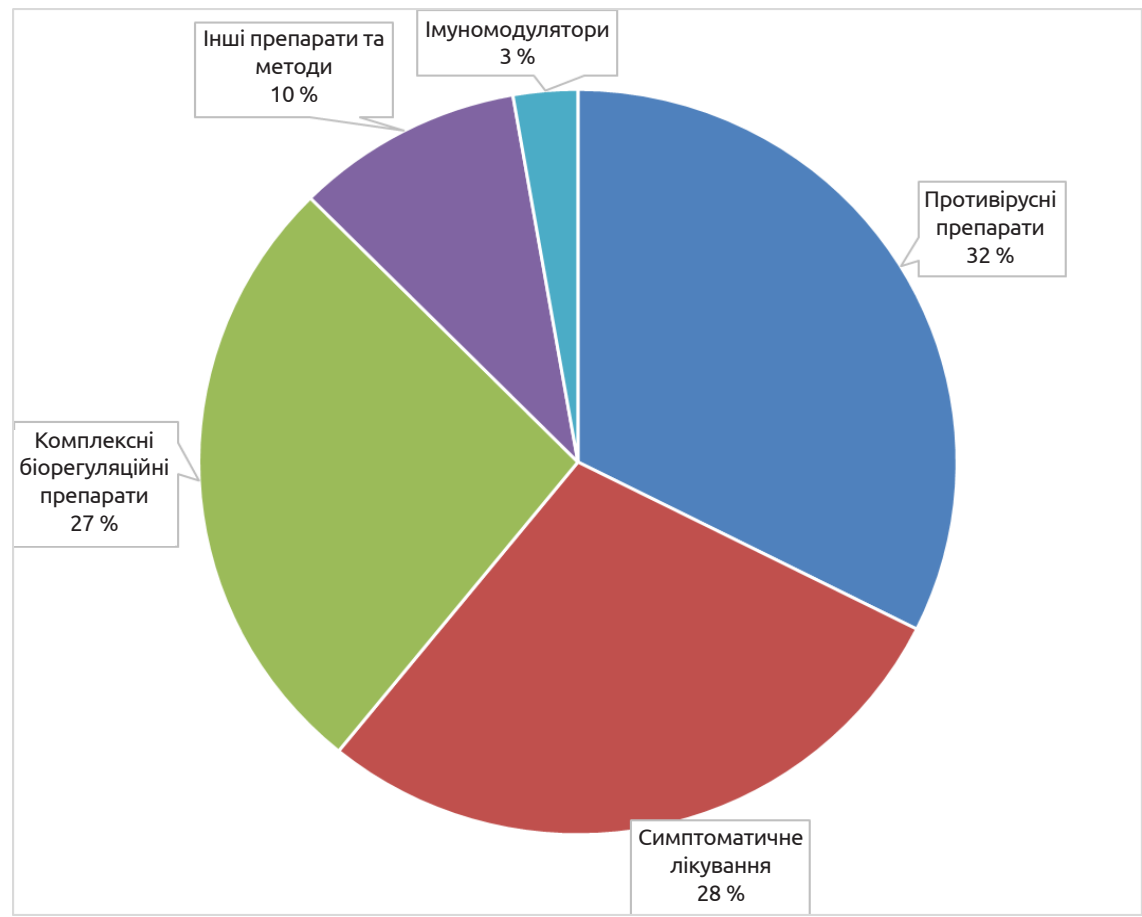

Рис. 4. Аналіз засобів лікування ГРІ пацієнтів - дорослих і дітей, - які застосовували лікарі, що брали участь у даному дослідженні.

Для лікування ускладнень ГРІ (рис. 5) у дорослих та дітей 56 \% пацієнтам призначали антибактеріальну терапію, причому в більшості випадків не проводячи попередній тест на чутливість до антибіотиків. Часто антибактеріальна терапія проводилася за вимогою батьків хворих дітей, через страх ускладненого перебігу і без урахуван- ня чітких показань до цього виду терапії. Однак, як свідчать дані ВООЗ та науковців, саме недоцільне та неконтрольоване застосування антибактеріальних препаратів призводить до значної кількості випадків антибіотикорезистентності, імунодефіцитів, дисбіозів та інших патологічних станів $[14-16,18,28]$. 


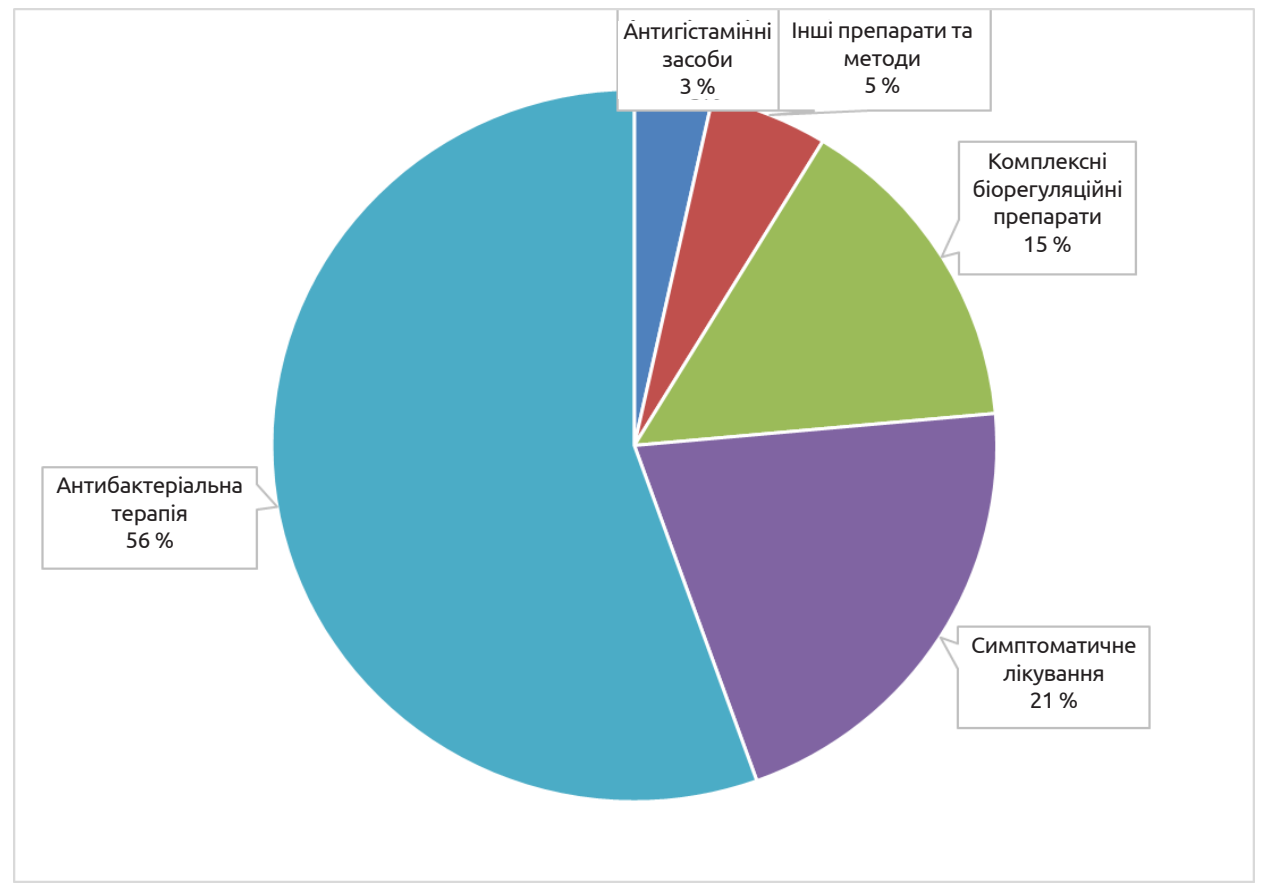

Рис. 5. Аналіз засобів лікування ускладнень ГРІ у пацієнтів - дорослих і дітей, - які застосовували лікарі, що брали участь у даному дослідженні.

Проаналізовані вище результати анамнестично-статистичного дослідження, проведеного нами, а також дані літературного огляду мотивували до включення в стандартно-протокольну схему лікування пацієнтів з ГPI засобу біорегуляційної дії, спрямованого на ефективне розрішення запального процесу, імунотропну і детоксикаційну дії з метою ефективного лікування хвороби і профілактики можливих ускладнень.

За результатами дослідження (рис. 6, 7), констатували швидку позитивну динаміку за вербально-аналоговою шкалою в основних групах пацієнтів - дорослих і дітей, які додатково приймали БРП Траумель С. Запропонована схема сприяла статистично достовірно більш значимій динаміці елімінації симптомів ГРІ: зниження температури, покращення самопочуття вже під час 2-го візиту, повне зникнення симптоматики ГРІ у більшості пацієнтів на третьому тижні лікування. Дані у когортах дорослих, наведені на рисунку 6, були статистично достовірними $(p \leq 0,05)$.

Щодо виникнення ускладнень, то серед 100 дорослих пацієнтів у контрольній групі запальні ускладнення дихальних шляхів (синусит, ларинготрахеїт, бронхіт тощо) виникли у 47 (47,0 \%) пацієнтів, в основній групі 100 дорослих з ГРІ-лише у 10 хворих (10,0\%). Клінічний перебіг ГРІ в контрольній групі зумовлював потребу в застосуванні НПЗП у 64 (64,0 \%) пацієнтів, в основній групі лише у 15 пацієнтів (15,0%). Антибіотикотерапія була введена до курсу лікування пацієнтів контрольної групи у 33 (33,0 \%) випадках, тоді як в основній - лише у двох (2,0\%). У контрольній групі лише в одному випадку було діагностовано негоспітальну пневмонію, що потребувала госпіталізації. В основній групі випадків пневмонії не було.

Отримані дані свідчать про статистично достовірно вищу дієвість комплексного лікування із включенням до нього курсу таблетованого Траумелю С щодо купірування клінічної симптоматики ГРІ у пацієнтів - дорослих, а також щодо запобігання ускладненням запального характеру, що сприяло достовірно меншій потребі у застосуванні НПЗП і антибіотиків.

Серед 50 дітей контрольної групи ускладнення виникали у 38 (76,0 \%), тоді як серед пацієнтів основної групи - лише у 4 випадках (8,0 \%), що доводить профілактичний вплив Траумелю С на виникнення ускладнень ГРІ (рис. 7). У контрольній групі дітей з ГРІ лікарі змушені були призначати НПЗП у 41 випадку захворювання (82,0\%), а в основній групі лише у 10 (20,0%). Призначення антибіотиків у контрольній групі було необхідним у 32 випадках (64,0\%), в основній же групі - лише в одному (2,0 \%). Важливо зазначити, що антибіотикотерапію в основному призначали дітям з ГРІ контрольної групи вже на 2-му візиті, тоді як в основній групі на цьому візиті пацієнти констатували достовірне покращення стану. Це також 
Огляди літератури, оригінальні дослідження, погляд на проблему, випадок з практики, короткі повідомлення

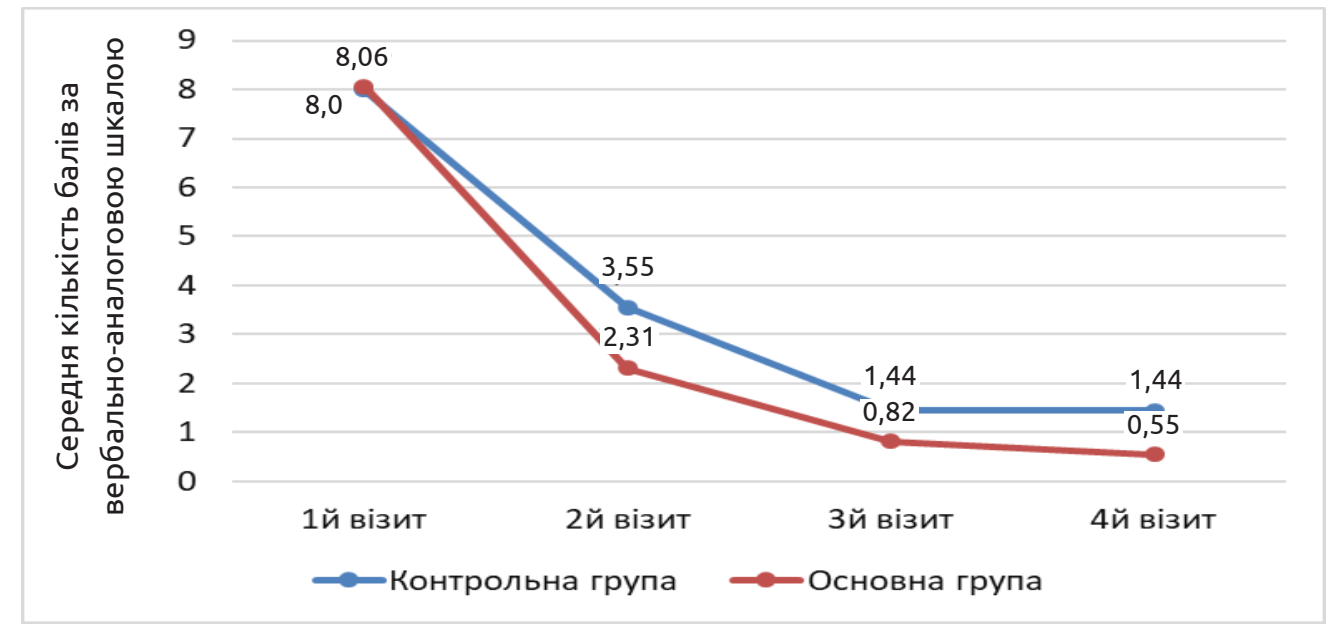

Рис. 6. Порівняльний аналіз динаміки клінічної симптоматики за вербально-аналоговою шкалою дорослих пацієнтів з ГPI ( $n=200)$ у групах дослідження $(p \leq 0,05)$.

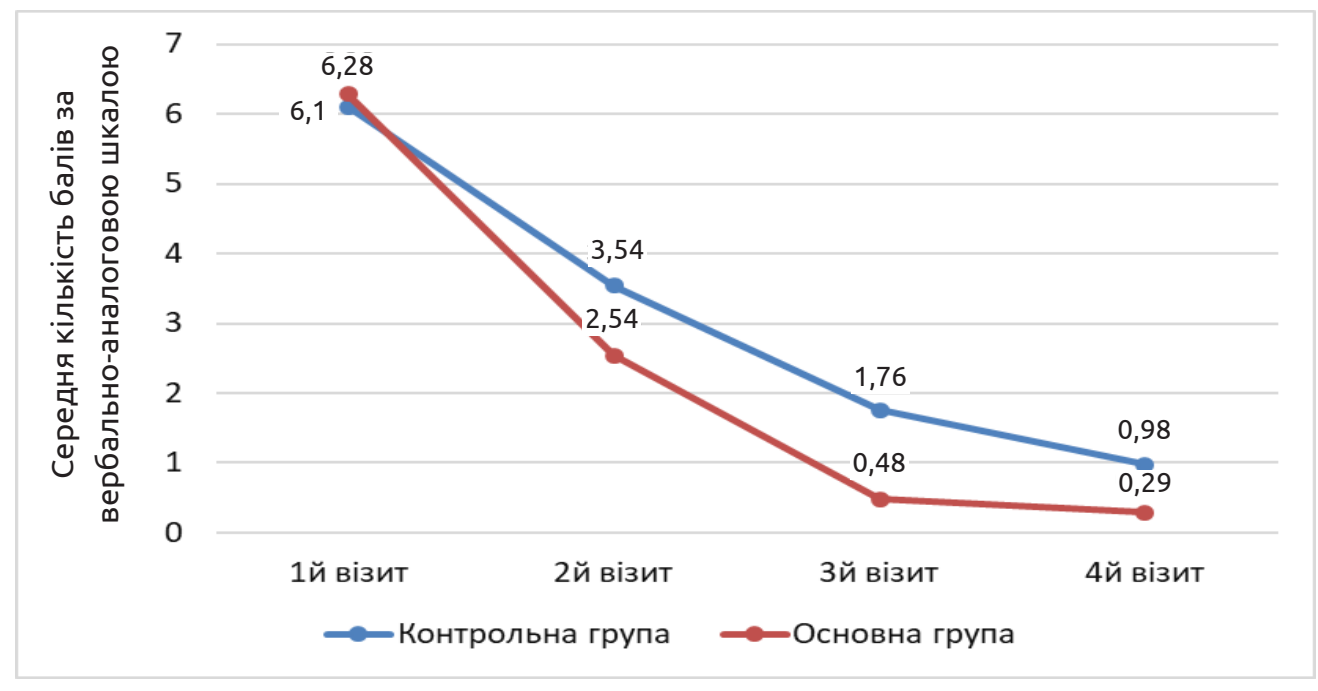

Рис. 7. Порівняльний аналіз динаміки клінічної симптоматики пацієнтів дитячого віку з ГРІ за вербальноаналоговою шкалою ( $n=100)$ у групах дослідження $(p \leq 0,05)$.

дозволяє стверджувати про позитивний лікувальний ефект Траумелю С при ГРІ, який сприяє профілактиці виникнення ускладнень.

Показовими виявилися також результати дослідження показників загального аналізу крові і С-реактивного протеїну. Як свідчать дані таблиці 2, практично всі параметри, які були патологічно зміненими і свідчили про наявність гострого інфекційного запального процесу в дорослих пацієнтів з ГРІ, під впливом лікування покращилися, причому в основній групі відбулась їх нормалізація. Ефективність лікувального комплексу із включенням Траумелю С була статистично достовірно вищою, порівняно зі стандартним лікуванням: на 12,5 \% - за зменшенням показника лейко- цитів, на 11,8 \% - за зменшенням паличкоядерних лейкоцитів, на 11,4 \% - за зменшенням сегментів, на 9,6 \% - за збільшенням лімфоцитів, на 6,6 \% за зменшенням ШОЕ, на 81,5 \% - за зменшенням C-реактивного протеїну $(p \leq 0,05)$.

Аналіз даних таблиці 3 дозволив зробити висновок щодо вищої ефективності лікувального комплексу, посиленого курсом Траумелю С, на всі патологічно змінені параметри загального аналізу крові пацієнтів дитячого віку: на 9,5 \% - за зменшенням показника лейкоцитів, на 11,8 \% - за зменшенням паличкоядерних лейкоцитів, на 6,7 \% - зменшенням сегментів, на 8,8 \% - за зменшенням еозинофілів, на 23,9 \% - за зменшенням ШОЕ, на 67,7 \% за зменшенням C-реактивного протеїну $(p \leq 0,05)$. 
Огляди літератури, оригінальні дослідження, погляд на проблему, випадок з практики, короткі повідомлення

Таблиця 2. Порівняльний аналіз динаміки показників загального аналізу крові і С-реактивного протеїну груп дослідження дорослих пацієнтів з ГРІ під впливом лікувальних комплексів

\begin{tabular}{|c|c|c|c|c|c|}
\hline \multirow[t]{2}{*}{ Лабораторний показник } & \multirow{2}{*}{$\begin{array}{c}\text { Показник } \\
\text { групи } \\
\text { здорових }\end{array}$} & \multicolumn{2}{|c|}{$\begin{array}{c}\text { Контрольна група } \\
\text { n=100 }\end{array}$} & \multicolumn{2}{|c|}{$\begin{array}{c}\text { Основна група } \\
n=100\end{array}$} \\
\hline & & до лікування & після лікування & до лікування & після лікування \\
\hline Лейкоцити, ×109/л & $5,9 \pm 0,7$ & $8,5 \pm 0,6$ & $7,2 \pm 1,3 *$ & $8,6 \pm 0,7$ & $6,3 \pm 0,4 * \#$ \\
\hline Еритроцити, ×1012/л & $4,2 \pm 0,5$ & $5,9 \pm 0,9$ & $4,7 \pm 0,8$ & $5,2 \pm 0,6$ & $4,7 \pm 0,4$ \\
\hline Гемоглобін, г/л & $135,0 \pm 1,5$ & $131,5 \pm 9,4$ & $131,4 \pm 21,1$ & $132,3 \pm 8,5$ & $132,3 \pm 9,5$ \\
\hline Тромбоцити, ×109/л & $259 \pm 26,4$ & $305,4 \pm 26,4$ & $301,8 \pm 20,3$ & $294,5 \pm 28,1$ & $294,1 \pm 18,0$ \\
\hline Паличкоядерні нейтрофіли, \% & $2,8 \pm 0,8$ & $6,8 \pm 1,8$ & $3,4 \pm 1,3 *$ & $7,04 \pm 2,0$ & $3,0 \pm 1,2 * \#$ \\
\hline Сегментоядерні нейтрофіли, \% & $52,3 \pm 4,0$ & $67,1 \pm 5,0$ & $56,5 \pm 3,1 *$ & $66,6 \pm 3,8$ & $50,1 \pm 4,8 * \#$ \\
\hline Лімфоцити, \% & $27,4 \pm 6,3$ & $24,7 \pm 3,3$ & $32,5 \pm 2,5^{*}$ & $24,8 \pm 2,5$ & $29,4 \pm 1,8 *$ \\
\hline Моноцити, \% & $3,8 \pm 0,3$ & $4,4 \pm 2,1$ & $4,1 \pm 1,6$ & $4,1 \pm 2,1$ & $4,2 \pm 1,9$ \\
\hline Еозинофіли, \% & $2,9 \pm 0,5$ & $2,4 \pm 0,3$ & $2,2 \pm 0,2$ & $2,2 \pm 0,3$ & $2,0 \pm 0,07$ \\
\hline ШОЕ, мм/год & $8,1 \pm 1,3$ & $17,9 \pm 3,7$ & $9,95 \pm 3,3 *$ & $17,0 \pm 3,2$ & $8,3 \pm 1,2 *$ \\
\hline С-реактивний протеїн, мг/л & $2,5 \pm 0,3$ & $7,2 \pm 0,9$ & $4,2 \pm 1,1 *$ & $7,0 \pm 1,3$ & $1,2 \pm 0,3 * \#$ \\
\hline
\end{tabular}

Примітка. * - достовірність різниць показників своєї групи до і після лікування $(p \leq 0,05)$;

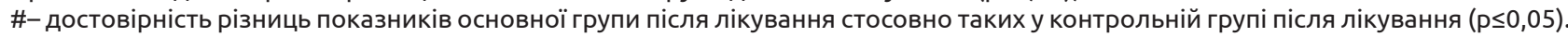

Таблиця 3. Порівняльний аналіз динаміки показників загального аналізу крові і С-реактивного протеїну груп дослідження пацієнтів дитячого віку з ГРІ під впливом лікувальних комплексів

\begin{tabular}{|c|c|c|c|c|c|}
\hline \multirow[t]{2}{*}{ Лабораторний показник } & \multirow{2}{*}{$\begin{array}{c}\text { Показник } \\
\text { групи } \\
\text { здорових }\end{array}$} & \multicolumn{2}{|c|}{$\begin{array}{c}\text { Контрольна група } \\
\text { n=50 }\end{array}$} & \multicolumn{2}{|c|}{$\begin{array}{c}\text { Основна група } \\
n=50\end{array}$} \\
\hline & & до лікування & після лікування & до лікування & після лікування \\
\hline Лейкоцити, ×109/л & $5,8 \pm 0,8$ & $8,5 \pm 0,4$ & $7,1 \pm 0,5^{*}$ & $9,4 \pm 0,7$ & $6,5 \pm 0,5 * \#$ \\
\hline Еритроцити, ×1012/л & $4,6 \pm 0,7$ & $5,0 \pm 0,9$ & $4,5 \pm 0,6$ & $5,0 \pm 0,6$ & $4,9 \pm 0,4$ \\
\hline Гемоглобін, г/л & $135,0 \pm 1,3$ & $131,4 \pm 7,4$ & $131,5 \pm 19,1$ & $133,3 \pm 8,5$ & $133,3 \pm 9,1$ \\
\hline Тромбоцити, ×109/л & $261 \pm 24,9$ & $263,4 \pm 26,4$ & $274,8 \pm 21,3$ & $281,5 \pm 22,1$ & $285,1 \pm 17,0$ \\
\hline Паличкоядерні нейтрофіли, \% & $2,8 \pm 0,8$ & $6,8 \pm 1,8$ & $3,4 \pm 1,3 *$ & $7,04 \pm 2,0$ & $3,0 \pm 1,2 * \#$ \\
\hline Сегментоядерні нейтрофіли, \% & $42,3 \pm 4,0$ & $47,1 \pm 4,0$ & $42,5 \pm 2,1^{*}$ & $49,6 \pm 2,8$ & $40,1 \pm 3,1 * \#$ \\
\hline Лімфоцити, \% & $41,4 \pm 5,3$ & $44,1 \pm 2,3$ & $49,5 \pm 2,1^{*}$ & $41,8 \pm 1,5$ & $50,4 \pm 1,8^{*}$ \\
\hline Моноцити, \% & $4,7 \pm 0,3$ & $7,4 \pm 2,1$ & $8,1 \pm 1,6$ & $7,1 \pm 2,1$ & $7,2 \pm 1,9$ \\
\hline Еозинофіли, \% & $2,9 \pm 0,5$ & $4,9 \pm 0,3$ & $3,2 \pm 0,2^{*}$ & $4,8 \pm 0,3$ & $2,6 \pm 0,2 * \#$ \\
\hline ШОЕ, мм/год & $8,1 \pm 1,3$ & $17,9 \pm 3,7$ & $10,9 \pm 3,3^{*}$ & $17,0 \pm 3,2$ & $8,3 \pm 1,2^{*}$ \\
\hline С-реактивний протеїн, мг/л & $7,1 \pm 0,4$ & $23,2 \pm 0,9$ & $9,3 \pm 1,1^{*}$ & $23,0 \pm 0,3$ & $3,1 \pm 0,5^{*} \#$ \\
\hline
\end{tabular}

Примітка. * - достовірність різниць показників своєї групи до і після лікування $(p \leq 0,05)$;

\# - достовірність різниць показників основної групи після лікування стосовно таких у контрольній групі після лікування (р $\leq 0,05)$.

Слід зазначити, що у пацієнтів - дітей включення Траумелю С, враховуючи вищий вихідний рівень лімфоцитів, не привело до достовірної динаміки даного показника, однак виявило достовірно значимий вплив на зниження еозинофілів, які були до лікування вище норми. Особливо цікавим виявилося дослідження С-реактивного протеїну у дітей: підвищений рівень цього маркера запалення часто не відповідав вираженості клінічної симптоматики. При цьому, за результатами лабораторного дослідження, виявили значно більше зниження показника впродовж лікування у основній групі дітей, порівняно з контрольною групою - на $67,7 \%(p \leq 0,05)$.
Таким чином, у групах пацієнтів, дорослих і дітей, котрі додатково приймали препарат Траумель С за запропонованою схемою, спостерігалася швидка позитивна динаміка зменшення інтенсивності симптомів (уже з першого тижня), зменшення потреби у прийомі НПЗП й антибіотиків, а також достовірно значиме зменшення кількості ускладнень, що довело високу лікувальну й профілактичну ефективність БРП Траумелю С у веденні пацієнтів з ГРІ.

Висновки. 1. Встановлено статистично достовірну вищу дієвість комплексного лікування із включенням до нього курсу таблетованого Траумелю С щодо купірування клінічної симптомати- 
Огляди літератури, оригінальні дослідження, погляд на проблему, випадок з практики, короткі повідомлення

ки ГРІ у пацієнтів - дорослих і дітей $(p \leq 0,05)$, а також щодо запобігання ускладнень запального характеру (ускладнення мали лише 10,0\% пацієнтів групи з Траумелем С і 47,0 \% - пацієнтів групи стандартного лікування), що сприяло достовірно нижчій потребі у застосуванні НПЗП і антибіотиків (лише 15,0 \% пацієнтів групи з Траумелем С потребували НПЗП і 2,0 \% - антибіотиків проти відповідно 64,0% і 33,0 \% пацієнтів групи стандартної терапії).

2. Ефективність лікування із включенням Траумелю С була вищою стосовно стандартного лікування: за зменшенням на 12,5 \% показника лейкоцитів, на 11,8 \% - паличкоядерних лейкоцитів, на 11,4 \% - сегментів, на 6,6 \% - ШОЕ, на 81,5 \% -
С-реактивного протеїну, на 9,6 \% - за збільшенням лімфоцитів $(p \leq 0,05)$.

3. Доведено вищу дієвість лікувального комплексу, посиленого курсом Траумелю С, на всі патологічно змінені параметри загального аналізу крові пацієнтів дитячого віку: зменшення на 9,5 \% - показника лейкоцитів, на 11,8 \% - паличкоядерних лейкоцитів, на 6,7 \% - сегментів, на 8,8 \% - еозинофілів, на 23,9 \% - ШОЕ, на 67,7 \% - С-реактивного протеїну $(p \leq 0,05)$.

Перспективи подальших досліджень полягають у науковому обґрунтуванні можливостей Траумелю С та інших препаратів з біорегуляційною дією у лікуванні запальних захворювань і з метою оптимізації власних захисних сил організму пацієнтів.

\section{ЛІТЕРАТУРА}

1. Сучасні класифікації та стандарти лікування захворювань внутрішніх органів. Невідкладні стани в терапії. Аналізи: нормативні показники, трактування змін / за ред. Ю. М. Мостового. - 26-те вид., змін. - К. : Центр ДЗК, 2019. -792 c.

2. Kočevar-Guček N. Akutne okužbe dihal (Acute Respiratory Infections) / N. Kočevar-Guček, V. Homar. In: Družinska medicina (Family Medicine) / I. Švab, D. RotarPavlič. - Ljubljana: Združenje zdravnikov družinske medicine (Association of Family Physicians), 2012. - P. 39-51.

3. Katić M. Family medicine / M. Katić, I. Švab. Izdavač: Medicinska naklada, Zagreb, 2017. - Vol. 512. P. 53-68.

4. https://phc.org.ua/news/zakhvoryuvanist-nagrip-ta-grvi-v-ukraini-pidsumki-epidemichnogo-sezonu-20182019.

5. Крамарєв С. О. Епідемія грипу в Україні / Крамарєв С. О. // 3 турботою про дитину : наук.-практ. журн. для педіатрів. - 2010. - № 1. - Р. 9-12.

6. WHO Library Cataloguing-in-Publication Data, The world health report 2018: primary health care now more than ever. WHO, 2018. - C. 152.

7. WHO: Influenza (Seasonal). WHO december 2011. Available at:http://www.who.int/mediacentre/factsheets/ fs211/en/.

8. https://www.cdc.gov/flu/about/burden/preliminaryin -season-estimates.htm.

9. Антипкін Ю. Г. Актуальні питання вакцинації дітей / Ю. Г. Антипкін // Перинатология и педиатрия. 2008. - № 4. - P. 11-12.

10. Newburg D. N. Protection of the neonate by the innate immune system of developing gut and of human milk / D. N. Newburg, W. A. Walker // Pediatric Research. 2004. - Vol. 61, No. 3. - P. $2-8$.

11. Бабінець Л. С. Захворювання органів дихання в сімейній медицині / Л. С. Бабінець, І. О. Боровик, Л. В. Андріюк. - К. : ВСВ «Медицина», 2019. - 250 с.

12. Міроненко А. П. Стратегії та стадії контролю грипу / А. П. Міроненко, В. О. Мухопад // Інфекційні хворо6и. - 2001. - № 2. - P. 55-58.

13. Бабінець Л. С. Актуальні питання діагностики і тактики ведення пацієнтів з ГРІ в амбулаторній практиці та викладанні / Л. С. Бабінець, Ю. Я. Коцаба // Здобутки клінічної і експериментальної медицини. - 2019. № 3. - P. 6-12.

14. Laine L. GI risk and risk factors of NSAIDs / L. Laine // J. Cardiovasc. Pharmacol. - 2016. - Vol. 47, Suppl. 1. P. 60-66.

15. Leong R. W. Drug-induced side effects affecting the gastrointestinal tract / R. W. Leong, F. K. Chan // Expert. Opin. Drug. Saf. - 2006. - Vol. 5 (4). - P. 585-592.

16. Fortun P. J. Nonsteroidal antiinflammatory drugs and the small intestine / P. J. Fortun, C. J. Hawkey // Curr. Opin. Gastroenterol. - 2007. - Vol. 23 (2). - P. 134-141.

17. Бабінець Л. С. Актуальні аспекти Європейського клінічного протоколу (Хорватія) щодо менеджменту гострої респіраторної інфекції в амбулаторній практиці і викладанні / Л. С. Бабінець // Сімейна медицина. 2019. - № 5. - P. 23-25.

18. National Institute for Health and Clinical Excellence (NICE). Respiratory tract infections - antibiotic prescribing. Prescribing of antibiotics for self limiting respiratory tract infections in adults and children in primary care (clinical guidelines) - London, UK: NICE, 2018. - Access mode : https://www.nice.org.uk/GeneralError?aspxerrorpath=/ nicmedia/phf/CG69\%20FullGuideline.\%20pdf.

19. Deep Sequencing Transcriptome Analysis of Murine Wound Healing: Effects of a Multicomponent, Multitarget Natural Product Therapy-Tr14 / G. St. Laurent III, B. Seilheimer, M. Tackett [et al.] // Front. Mol. Biosci. 2017. - Vol. 4. - P. 57. DOI:10.3389/fmolb.2017.00057.

20. AB0080 Differential effects of $t r 14$ versus diclofenac on pro-resolving lipid mediators revealed by rnaseq / G. St. Laurent, I. Toma, M. Tackett [et al.] // Ann. Rheum. Dis.-2018. - Vol. 77 (Suppl 2). -P. 1237-1238. DOI: 10.1136/ annrheumdis-2018-eular.3789.

21. Ефективність використання Траумель С у комплексному лікуванні гострого синуситу у дітей / О. І. Сміян, О. П. Мощич, Т. П. Бинда [та ін.] // Здоровье ребенка. - 2016. - № 4 (72). - С. 57-62. 
Огляди літератури, оригінальні дослідження, погляд на проблему, випадок з практики, короткі повідомлення

22. Ефективність використання Траумелю С у комплексному лікуванні гострого бронхіту у дітей / О. І. Сміян, О. П. Мощич, Т. П. Бинда, М. М. Дичко // Современная педиатрия. - 2016. - № 7 (79). - С. 2-6.

23. Бабінець Л. С. Ад'ювантні можливості біорегуляційного підходу до ведення пацієнтів із хронічним панкреатитом / Л. С. Бабінець // Здоров'я України. 2019. - № 17 (462). - Р. 46-47.

24. Крамарєв С. О. Альтернативні методи лікування та профілактики грипу та ГРВІ в дітей (Методичні рекомендації МОЗ України) / С. О. Крамарєв, Л. О. Палатна, Б. К. Шамугія. - К., 2006. - 37 с.

25. Хайне Х. Иммунологическая вспомогательная реакция, вызываемая растительными экстрактами, содержащимися в антигомотоксических препаратах / Х. Хайне, М. В. Шмольц // Биологическая медицина. 1998. - № 2. - C. 9-11.

\section{REFERENCES}

1. Mostovoho, Yu.M. (2019). Suchasni klasyfikatsii ta standarty likuvannia zakhvoriuvan vnutrishnikh orhaniv. Nevidkladni stany v terapii. Analizy: normatyvni pokaznyky, traktuvannia zmin [Modern classifications and standards of treatment of diseases of internal organs. Emergencies in therapy. Analyzes: normative indicators, interpretation of changes]. Kyiv: Tsentr DZK [in Ukrainian].

2. Kočevar-Guček, N., \& Homar, V. (2012). Akutne okužbe dihal (Acute Respiratory Infections). Družinska medicina (Family Medicine) in I. Švab, D. Rotar-Pavlič. Ljubljana: Združenje zdravnikov družinske medicine (Association of Family Physicians).

3. Katić, M., \& Švab, I. (2017). Family medicine. Izdavač: Medicinska naklada, Zagreb, 512, 53-68.

4. https://phc.org.ua/news/zakhvoryuvanist-nagrip-ta-grvi-v-ukraini-pidsumki-epidemichnogo-sezonu-20182019.

5. Kramaryev, S.O. (2010). Epidemiia hrypu v Ukraini [The flu epidemic in Ukraine]. Z turbotoiu pro dytynu: nauk.prakt. zhurn. dlia pediatriv - With care for the child: scientificpractical. magazine for pediatricians, 1, 9-12 [in Ukrainian].

6. (2018). WHO Library Cataloguing-in-Publication Data, The world health report 2018: primary health care now more than ever. WHO.

7. WHO: Influenza (Seasonal). WHO. Retrieved from: http://www.who.int/mediacentre/factsheets/fs211/en/.

8. https://www.cdc.gov/flu/about/burden/preliminaryin-season-estimates.htm.

9. Antypkin, Yu.H. (2008). Aktualni pytannia vaktsynatsii ditei [Current issues of vaccination of children]. Perynatolohiia i pediatriia - Perinatology and Pediatrics, 4, 11-12 [in Ukrainian].

10. Newburg, D.N., \& Walker, W.A. (2004). Protection of the neonate by the innate immune system of developing gut and of human milk. Pediatr. Res.,61, 3, 2-8.

11. Babinets, L.S., Borovyk, I.O., \& Andriyuk, L.V. (2019). Zakhvoriuvannia orhaniv dykhannia v simeinii medytsyni [Respiratory diseases in family medicine]. Kyiv: VSV "Medytsyna" [in Ukrainian].
26. Traumeel vs. diclofenac for reducing pain and improving ankle mobility after acute ankle sprain: A multicentre, randomised, blinded, controlled and non-inferiority trial / C. González de Vega, C. Speed, B. Wolfarth, J. González // Int. J. Clin. Pract. - 2013. - Vol. 979-989. DOI:10.1111/ijcp.12219.

27. Vanden Bossche L. A multi-center, double-blind, randomized, placebo-controlled trial protocol to assess Traumeel injection vs dexamethasone injection in rotator cuff syndrome: the TRAumeel in ROtator cuff syndrome (TRARO) study protocol / L. Vanden Bossche, G. Vanderstraeten //BMC Musculoskelet Disord. -2015. - Vol. 16.-P. 8. Access mode : https://doi.org/10.1186/s12891-015-0471-z.

28. Гуменюк М. І. Антибіотикорезистентність мікроорганізмів. Стан проблеми та шляхи вирішення / М.І.Гуменюк, О.С.Денисов, Ю.І. Фещенко // Український хіміотерапевтичний журнал. -2010. - № 1-2 (23). - С. 4-10.

12. Mironenko, A.P., \& Mukhopad, V.O. (2001). Stratehii ta stadii kontroliu hrypu [Strategies and stages of influenza control]. Infektsiini khvoroby - Infectious Diseases, 2, 55-58 [in Ukrainian].

13. Babinets, L. S., \& Kotsaba, Y. Y. (2019). Aktualni pytannia diahnostyky i taktyky vedennia patsiientiv z HRI v ambulatornii praktytsi ta vykladanni [Actual issues of diagnostics and management tactics of patients with acute respiratory infections in outpatient practice and teaching]. Zdobutky klinichnoi i eksperymentalnoi medytsyny - Achievements of Clinical and Experimental Medicine, 3, 6-12. Retrieved from: https://doi.org/10.11603/18112471.2019.v.i3.10437 [in Ukrainian].

14. Laine, L. (2016). GI risk and risk factors of NSAIDs. J. Cardiovasc. Pharmacol., 47, (1), 60-66.

15. Leong, R.W., \& Chan, F.K. (2006). Drug-induced side effects affecting the gastrointestinal tract. Expert. Opin. Drug. Saf., 5 (4), 585-592.

16. Fortun, P.J., \& Hawkey, C.J. (2007). Nonsteroidal antiinflammatory drugs and the small intestine. Curr. Opin. Gastroenterol., 23 (2), 134-141.

17. Babinets, L.S. (2019). Aktualni aspekty Yevropeiskoho klinichnoho protokolu (Khorvatiia) shchodo menedzhmentu hostroi respiratornoi infektsii v ambulatornii praktytsi i vykladanni [Actual aspects of the European clinical protocol (Croatia) on the management of acute respiratory infection in outpatient practice and teaching]. Simeina medytsyna - Family Medicine, 5, 23-25 [in Ukrainian].

18. National Institute for Health and Clinical Excellence (NICE). (2018). Respiratory tract infections - antibiotic prescribing. Prescribing of antibiotics for self limiting respiratory tract infections in adults and children in primary care (clinical guidelines). London, UK: NICE. Retrieved from: https://www.nice.org.uk/GeneralError?aspxerrorpath=/nicmedia/phf/CG69\%20FullGuideline.\%20pdf.

19. St. Laurent III, G., Seilheimer, B., Tackett, M., Zhou, J., Shtokalo, D., Vyatkin, Y., ..., \& McCaffrey, T.A. (2017). Deep sequencing transcriptome analysis of murine wound healing: effects of a multicomponent, multitarget 
Огляди літератури, оригінальні дослідження, погляд на проблему, випадок з практики, короткі повідомлення natural product therapy - Tr14. Front. Mol. Biosci., 4, 57. DOI:10.3389/fmolb.2017.00057.

20. St. Laurent, G., Toma, I., Tackett, M., Zhou, J., Ri, M., Shtokalo, D., ..., \& Mccaffrey, T. (2018). AB0080 Differential effects of $t r 14$ versus diclofenac on pro-resolving lipid mediators revealed by rnaseq. Ann. Rheum. Dis., 77 (2), 1237-1238. DOI: 10.1136/annrheumdis-2018-eular.3789.

21. (2016). Efektyvnist vykorystannia Traumel S u kompleksnomu likuvanni hostroho synusytu u ditei [The effectiveness of the use of Traumel $C$ in the complex treatment of acute sinusitis in children]. Zdorovye rebenka Child's Health, 4 (72), 57-62.

22. Smiyan, O.I., Moshchych, O.P., Bynda, T.P., \& Dychko, M.M. (2016). Efektyvnist vykorystannia Traumel S u kompleksnomu likuvanni hostroho synusytu u ditei [The effectiveness of the use of Traumel $\mathrm{C}$ in the complex treatment of acute sinusitis in children]. Zdorovye rebenka Child's Health, 4 (72), 57-62 [in Ukrainian].

23. Babinets, L.S. (2019). Adiuvantni mozhlyvosti biorehuliatsiinoho pidkhodu do vedennia patsiientiv iz khronichnym pankreatytom [Adjuvant possibilities of bioregulatory approach to the management of patients with chronic pancreatitis]. Zdorovia Ukrainy - Health of Ukraine, 17 (462), 4647 [in Ukrainian].

24. Kramaryev, S.O., Palatna, L.O., \& Shamuhiya, B.K. (2006). Alternatyvni metody likuvannia ta profilaktyky hrypu ta HRVI v ditei (Metodychni rekomendatsii MOZ Ukrainy) [Alternative methods of treatment and prevention of influ-

enza and SARS in children (Methodical recommendations of the Ministry of Health of Ukraine)]. Kyiv [in Ukrainian].

25. Khayne, Kh., \& Shmolts, M.V. (1998). Immunologicheskaya vspomogatelnaya reaktsiya, vyzyvayemaya rastitelnymi ekstraktami, soderzhashchimisya v antigomotoksicheskikh preparatakh [Immunological auxiliary reaction caused by plant extracts contained in antihomotoxic drugs]. Biologicheskaya meditsina-Biological Medicine, 2, 9-11 [in Russian].

26. González de Vega, C., Speed, C., Wolfarth, B., \& González, J. (2013). Traumeel vs. diclofenac for reducing pain and improving ankle mobility after acute ankle sprain: A multicentre, randomised, blinded, controlled and noninferiority trial. Int. J. Clin. Pract., 979-989. DOI:10.1111/ ijcp.12219.

27. Vanden Bossche, L., \& Vanderstraeten, G. (2015). A multi-center, double-blind, randomized, placebo-controlled trial protocol to assess Traumeel injection vs dexamethasone injection in rotator cuff syndrome: the TRAumeel in ROtator cuff syndrome (TRARO) study protocol. BMC Musculoskelet Disord., 16, 8. Retrieved from: https:// doi.org/10.1186/s12891-015-0471-z.

28. Humenyuk, M.I., Denysov, O.S., \& Feshchenko, Yu.I. (2010). Antybiotykorezystentnist mikroorhanizmiv. Stan problemy ta shliakhy vyrishennia [Antibiotic resistance of microorganisms. The state of the problem and solutions]. Ukrainskii khimioterapevtychnyi zhurnal - Ukrainian Journal of Chemotherapy, 1-2 (23), 4-10 [in Ukrainian].

\title{
КЛИНИКО-ПАТОГЕНЕТИЧЕСКОЕ ОБОСНОВАНИЕ ДЕЙСТВЕННОСТИ БИОРЕГУЛЯЦИОННОГО ПРЕПАРАТА ТРАУМЕЛЬ С В ЛЕЧЕНИИ И ПРОФИЛАКТИКЕ ОСЛОЖНЕНИЙ ОСТРЫХ РЕСПИРАТОРНЫХ ИНФЕКЦИЙ
}

\author{
๑Л. С. Бабинец, М. А. Гулий, Н. Г. Лерман
}

Тернопольский национальный медицинский университет имени И. Я. Горбачевского мОз Украины Уз «Украинская Академия биорегуляционной медицины»

РЕЗЮМЕ. Ежегодно в Украине регистрируется 4,0-4,8 млн случаев острых респираторных инфекций (ОРИ) и гриппа, что делает тему исследования актуальной. Наиболее рациональным подходом к ведению пациентов с ОРИ является профилактический. Именно поэтому в последние годы все чаще, кроме общепризнанной в мире тактики ведения больных с ОРИ «Ожидай и наблюдай», ученые и практики рекомендуют адъювантные средства, которые повышают сопротивляемость организма к инфекциям и восстанавливают нарушенные функции органов и систем больного человека.

Цель - изучение эффективности применения препарата Траумель С при неосложненной острой респираторной инфекции у взрослых и детей для профилактики возникновения осложнений верхних и нижних дыхательных путей воспалительного генеза.

Материал и методы. Для достижения поставленной цели было проведено многоцентровое открытое проспективное сравнительное клиническое испытание на 300 пациентах (200 взрослых и 100 детей) с подтвержденным диагнозом ОРИ. Продолжительность исследования составила 21 день, курс лечения - 14 дней, период наблюдения - 7 дней. В испытании принимали участие взрослые (мужчины и женщины в возрасте 18-65 лет) и дети обоего пола (в возрасте 1-18 лет).

Результаты. Установлено статистически достоверно высшую действенность комплексного лечения с включением в него курса таблетированного препарата Траумель С для купирования клинической симптоматики ОРИ у пациентов - взрослых и детей ( $\leq 0,05)$, а также для предупреждения осложнений воспалительного характера (осложнения имели только 10,0 \% пациентов группы с Траумель С и 47,0 \% пациентов группы стандартного лечения), что способствовало достоверно меньшей потребности в применении НПВП и антибиотиков (только 15,0\% пациентов группы с Траумель нуждались в НПВП и 2,0% - в антибиотиках относительно соответственно 64, 0 \% и 33,0\% у пациентов группы стандартной терапии). 
Огляди літератури, оригінальні дослідження, погляд на проблему, випадок з практики, короткі повідомлення

Выводы. Эффективность лечения с включением Траумель С была выше относительно стандартного лечения: по уменьшению на 12,5 \% показателя лейкоцитов, на 11,8 \% - палочкоядерных лейкоцитов, на 11,4 \% - сег-

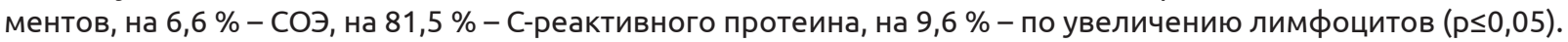

3. Доказана более высокая действенность лечебного комплекса, усиленного курсом Траумель С, на все патологически измененные параметры общего анализа крови пациентов детского возраста: уменьшение на 9,5 \% показателя лейкоцитов, на 11,8 \% - палочкоядерных лейкоцитов, на 6,7 \% - сегментов, на 8,8 \% - эозинофилов, на

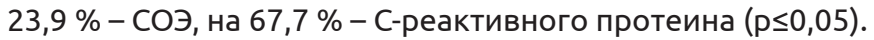

КЛЮЧЕВЫЕ СЛОВА: острая респираторная инфекция; грипп; биорегуляционный препарат; разрешение воспаления; лечение и профилактика осложнений; траумель С.

\title{
CLINICO-PATHOGENETIC JUSTIFICATION OF THE BIORREGULATORY DRUG TRAUMEL S EFFICACY IN THE TREATMENT AND COMPLICATIONS PREVENTION AT ACUTE RESPIRATORY INFECTIONS
}

\author{
@L. S. Babinets, M. A. Guliy, N. G. Lerman \\ I. Horbachevsky Ternopil National Medical University \\ Ukrainian Academy of Bioregulatory Medicine
}

SUMMARY. Every year 4.0-4.8 million cases of acute respiratory infections (ARI) and influenza are registered in Ukraine, which makes the research topic relevant. The most rational approach to the management of patients with ARI is a preventive approach. That is why in recent years scientists and practitioners have been recommending adjuvants that increase the body's resistance to infections and restore the damaged functions of organs and systems of the sick person to the increasingly well-known tactics of managing patients with ARI "Expect and observe".

The aim of the study - to learn the effectiveness of the drug Traumel S in uncomplicated acute respiratory infection in adults and children to prevent complications of the upper and lower respiratory tract of inflammatory origin.

Material and Methods. To achieve this goal, a multicenter open prospective comparative clinical trial was conducted on 300 patients (200 adults and 100 children) with a confirmed diagnosis of ARI. The duration of the study was 21 days: the course of treatment -14 days, the observation period - 7 days. Adults (men and women aged 18-65 years) and children of both sexes (aged 1-18 years) took part in the trial.

Results and Discussion. There was a statistically significant higher efficacy of complex treatment with the inclusion the tablets Traumel S course on the relief of clinical symptoms of ARI in patients and adults ( $p \leq 0.05)$, as well as on the prevention of inflammatory complications (complications were only $10.0 \%$ of patients group with Traumel S and $47.0 \%$ patients of the standard treatment group), which contributed to a significantly lower need for NSAIDs and antibiotics (only $15.0 \%$ of patients in the group with Traumel S required NSAIDs and $2.0 \%$ - antibiotics in relation to $64.0 \%$ and $33.0 \%$ of patients in the standard therapy group).

Conclusions. The effectiveness of treatment with the inclusion of Traumel S was higher than standard treatment: a decrease of $12.5 \%$ in leukocytes, $11.8 \%$ - rod-shaped leukocytes, $11.4 \%$ - segments, $6.6 \%$ - ESR, $81.5 \%$ - C-reactive protein, $9.6 \%$ - an increase in lymphocytes ( $p \leq 0.05)$.

The higher efficiency of the medical complex strengthened by a course of Traumel $S$, on all pathologically changed parameters of the general analysis of blood of patients of children's age is proved: decrease by $9.5 \%$ - indicator of leukocytes, by $11.8 \%$ - rod-shaped leukocytes, by $6.7 \%$ - segments, $8.8 \%$ - eosinophils, $23.9 \%$ - ESR, $67.7 \%$ - C-reactive protein ( $p \leq 0.05)$.

KEY WORDS: acute respiratory infection; influenza; bioregulatory drug; resolution of inflammation; treatment and prevention of complications; Traumel S.

Отримано 27.08.2020 